and in the dry state. These early papers deal primarily with the definition of the properties to be measured, with methods of measurement, and with instruments for making the measurements. As soon as the methods were so perfected that reproducibility was possible, it became evident that further progress in the realm of the physical and chemical properties was dependent on the nature of the sample. This work culminated in 1929 in a description of a procedure for making a standard gelatin by methods easily reproduced in the laboratories. A scientifically valuable by-product of this work was the manufacture and consequent availability of such a standard de-ashed gelatin to laboratories in general, biological as well as chemical.

After the First World War, Sheppard began to turn his attention to the structure and properties of silver halide emulsions, and his first work took the form of a study of the distribution of the sizes of the silver halide grains in an emulsion, the intention being to work out the relation between this distribution and the sensitometric properties of the material. Thus began a long series of studies that are not yet completed, though much progress has been made in the last thirty years. At the same time, working with Dr. Ludwik Silberstein and with Mr. A. P. H. Trivelli, Sheppard began to consider the action of light on the halides and the nature of sensitivity, and about 1923 a series of papers was published on the theory of photographic sensitivity and of exposure, which resulted in the presentation of the concentration speck hypothesis, according to which the sensitivity was related to discontinuities in the silver bromide lattice, presumably due to some foreign substance. At the same time, a very notable group of studies was going forward on the measurement of size frequency distribution, which led to the development of microscopic methods by which the grain-size frequency distribution could be measured for practical silver bromide emulsions.

The well-known sensitizing property of gelatin in the photographic process led to a systematic study of the difference between photographic gelatins in their sensitizing power and the nature of the substance in gelatin which conferred sensitivity. By a painstaking series of analyses, it was found that the sensitizer inherent in natural gelatin was concentrated in the liquors obtained by the acid treatment of the raw material after liming; and eventually it was found that the chemical properties of the sensitizer corresponded to those of allyl thiourea, and that therefore the gelatin sensitizer was essentially one which could produce silver sulphide specks in the silver bromide crystals.

This discovery is perhaps the major advance made in Sheppard's scientific career. All further study of the photographic properties of gelatin, of the nature of the sensitivity of silver halides and of the latent image have been conditioned by it. Its publication won for Sheppard instant recognition. He was awarded the Adelsköld Medal of the Swedish Photographic Society in 1929, the Progress Medal of the Royal Photographic Society in 1928, and the honorary fellowship of the Royal Photographic Society in 1926. In 1928 he delivered the Hurter and Driffield Memorial Lecture to the Royal Photographic Society, and in 1930 received the Nichols Medal of the American Chemical Society.

From that time, Sheppard's scientific work covered a prodigious range of knowledge. Besides the work on the latent image, he studied such matters as the photovoltaic effects, that is, the electrical response of silver halide to light, the colloidal structure of film. base materials and their physico-chemical and elastic properties, the nature of development, and particularly the nature of dye sensitizing, the adsorption of sensitizing dyes to silver halides, the structure of the layers which they formed, and their sensitizing effects.

Sheppard realized that the solution of the problem of dye sensitizing would involve not only the coupling of the dye to the silver halide lattice by absorption, but also an understanding of the nature of the absorption of light by the resonance structure of the dye. Thus he studied the absorption spectra of dyes in various solvents, in vapour phases, and when adsorbed to surfaces. This is the field which was chiefly engaging his attention when his health failed.

While never robust, Sheppard enjoyed good health until a few years ago, when he began to have trouble with his eyes, which culminated in the loss of one eye from glaucoma. At the same time, his heart was affected, and continued to fail until in January 1948 he found it necessary to resign from his position with the Kodak Company.

More than any other single worker, Sheppard has been responsible for our present knowledge of the theory of the photographic process. He explored every section of the chemistry of that process, and everywhere his studies brought light.

$$
\text { C. E. K. Mees }
$$

\section{Prof. Kornél de Körösy}

We regret to announce that Dr. Kornél de Körösy, professor of biology in the University of Budapest, died on July 14. Son of the famous Hungarian statistician, Joseph de Kürösy, he was born at Budapest in 1879. As a student of medicine, he entered the Institute of Physiology in the University of his native city, never to leave it permanently until his death.

Until the First World War he was mainly interested in problems of metabolism, especially in those of resorption, and one of his publications foreshadowed the insulin problem. He spent at that time practically all his summer vacations at some world centre of learning. On one such occasion, in New York, Jaques Loeb invited him to stay at the Rockefeller Institute, where they were working together on osmotic problems; but K"öösy decided to return to Hungary, which proved fatal for his life and career.

During most part of the First World War and some time after, he was acting director of the Physiological Institute, shouldering an unusual load of teaching in difficult circumstances. Anti-semitic racial prejudice, rising quickly after the War, forced him from this position and practically stopped his experimental work. He turned to genetics and developed a mathematical theory of coupling between genes, published as a long monograph in German. During the last ten years of his life he eleared up important problems on crossing-over interference.

Political terror made him conscious of his Jewish duties, and he soon rose to the presidency of the Hungarian Pro-Palestina Association. The Nazis deported his younger son, who failed to return. The months of terror, the loss of access to his precious library and files, even after the War, hastened his death.

Prof. K"öösy belonged to those men whose respect for truth and justice was embedded in a nature fond 
of beauty and full of humanitarian sentiment. $\mathrm{He}$ was a well-known figure at physiological congresses in Paris, Budapest, London, Boston, Leningrad, Venice, Edinburgh, and was loved for his kindly, gentle nature by friends and students the world over. Music was his favourite recreation, and he loved to travel, always taking his family with him. His wife, whom he married early in life, and three of his children, survive him.

M. Polanyi

We regret to announce the following deaths:

Sir Wilfrid Grigson, C.S.I., sometime directorgeneral of revenue in Hyderabad, author of "The
Aboriginal Problem in the Central Provinces and Berar" and other anthropological studies, on November 26, aged fifty-two.

Dr. Louis Rapkine, director of the Department of Cell Chemistry, Pasteur Institute, Paris, on December 13.

Dr. Marjory Stephenson, M.B.E., F.R.S., of the Medical Research Council Unit for Chemical Microbiology, on December 12, aged sixty-two.

We are glad to learn from Prof. J. Heyrovský, of the Charles University, Prague, that Dr. F. Bøhounek, whose death was announced in Nature of December 4, is alive and well.

\section{NEWS and VIEWS}

U.S. National Academy of Sciences: Agassiz Medal

THE National Academy of Sciences presented the Alexander Agassiz Gold Medal and honorarium for 1948 to Dr. Thomas Gordon Thompson at the autumn meeting of the Academy held at the Univ. ersity of California, Berkeley, on November 15. Dr. Thompson, professor of chemistry and director of the oceanographic laboratories of the University of Washington at Seattle and Friday Harbor in the State of Washington, has long been a leader in investigations of the complex chemistry of the ocean, with special attention to the waters of the north-east Pacific, Puget Sound, the San Juan Archipelago and the Bering and Chukchi Seas. Under his inspiration and leadership, his associates and students have devised and developed effective methods and techniques for the isolation and the quantitative determination of many of the elements and their compounds which occur in minute concentrations in sea water. Examples of such are iron, lithium, silicon, manganese, aluminium, boron and radium, the fluorides, phosphates and silicates, the isotopes of the elements of water and the dissolved gases, and the ionic ratios of the major constituents of sea water in various parts of the ocean. In organising the oceanographic laboratories at Seattle and Friday Harbor, Dr. Thompson brought together specialists in the fundamental sciences associated with the various departments of a great university, and directed their attention and stimulated their interest in the many problems presented by oceanic phenomena. Dr. Thompson has been chairman of various international committees, particularly the committee of the International Association of Physical Oceanography, appointed for the purpose of establishing standard units and procedures for the promotion of studies of the chemistry of the ocean. Established by Sir John Murray in 1911, the Alexander Agassiz Gold Medal is awarded by the Academy "for original contribution in the science of oceanography to scientific men in any part of the world"

\section{William Davidson of Aberdeen : 1648}

A Tercentenary Memorial Lecture ontitled "William Davidson of Aberdeen : The First Scots Professor of Chemistry" was delivered in Marischal College, Aberdeen, on November 26, 1948, by Dr. John Read, professor of chemistry in the University of St. Andrews. Davidson was a native of Aberdeenshire who graduated at Marischal College in 1617 and then migrated to France. Here he became known as an authority on medicine, pharmacy and chemistry. He gave instruction in medical chemistry of the Paracelsian type, and was appointed a physician to the French king. In 1647 he was nominated to the first chair of chemistry to be founded in France, at the Jardin du Roi in Paris, where he entered upon his duties in 1648. Davidson was one of the three earliest occupants of a chair of chemistry, and the first native of the British Isles to become a professor of chemistry. Owing to religious and medical jealousies, he was forced to resign the chair in 1651 ; thenceforward, until 1667 , he was chief physician to the King of Poland. He died in Paris in 1669. Besides various medical works, Davidson wrote an early text-book of chemistry entitled "Philosophia Pyrotechnica". Although imbued with the ideas of his alchemical predecessors, and given to associating the doctrines of chemistry with religious and metaphysical conceptions, he has claims to be called a chemist rather than an alchemist. Davidson was particularly proud of the blue blood of Scotland that ran in his veins; in 1629 he obtained a patent of nobility from Charles I and thereafter styled himself 'Nobilis Scotus'. To account for his entering the medical profession he told his readers that "professors of medicine were invested with such honour by the kings of Scotland that they enjoyed a title equal to that of earls".

\section{U.S. Scientific Mission to Japan}

Tнғ Supreme Commander, Allied Powers ('SCAP') has announced that a United States scientific mission to Japan "is scheduled to arrive in that country on or about November 26 and may be expected to remain until about December 18, 1948". The mission is composed of five distinguished American men of science, selected by the National Academy of Sciences, and includes : Dr. Detlev W. Bronk, chairman of the National Research Council, foreign secretary of the National Academy of Sciences, and president-elact of Johns Hopkins University ; Dr. E. C. Stakman, chief of the division of plant pathology and botany, University of Minnesota; Dr. Zay Jeffries, vice-president of the General Electric Company, and general manager of its chemical department; Dr. I. I. Rabi, professor of physics, Columbia University ; Dr. Roger Adams, head of the department of chemistry, University of Illinois, and chairman of the scientific advisory group that visited Japan in 1947. Dr. Bronk is chairman of the present mission. The new mission is making the visit at a time when some forty 